Application of Picture Word Inductive Model Strategy in English Descriptive Text to improve Student Achievement for Class VII ${ }^{1}$ SMP Negeri 1 Brang Rea

\title{
Penerapan Strategi Picture Word Inductive Model dalam Menyusun Teks Deskriptif Berbahasa Inggris untuk Meningkatkan Prestasi Belajar Siswa Kelas VII-1 SMP Negeri 1 Brang Rea
}

\author{
Elmy Latifah \\ doi: https://doi.org/10.51518/lentera.v3i2.53
}

email: elmilatifah@gmail.com

Guru Bahasa Inggris pada SMP Negeri 1 Brang Rea - Kab. Sumbawa Barat

\begin{abstract}
This study aims to improve the learning outcomes of grade VII-1 students of SMP Negeri 1 Brang Rea for the even semester of 2018/2019 in learning English, especially in describing certain objects, people, or places through the Picture Word Inductive Model learning strategy. The type of research used is Classroom Action Research (CAR), while the research subjects are 31 -grade $\mathrm{VII}^{1}$ students of SMP Negeri 1 Brang Rea in the even semester of the 2018/2019 academic year. Data collection is carried out simultaneously with observations during the action, while data analysis is carried out at the time of reflection of the action. From the results of the study, it was found that PWIM was significant in improving student learning outcomes in learning English, especially in describing certain objects/people/places for class VII- 1 in the even semester of the 2018/2019 academic year. The pedagogical implication of this research is that the use of the PWIM strategy can help students explore many words and then arrange them into a paragraph and descriptive text in English. With pictures of certain objects/people/places, students get inspired by what words they will write to compose a descriptive text.
\end{abstract}

Keywords: Picture word inductive model, Descriptive text, Achievement

\begin{abstract}
Abstrak: Penelitian ini bertujuan untuk meningkatkan hasil belajar siswa kelas VII-1 SMP Negeri 1 Brang Rea semester genap tahun ajaran 2018/2019 dalam pembelajaran menulis berbahasa Inggris, terutama dalam mendeskripsikan benda, orang atau tempat tertentu melalui strategi pembelajaran Picture Word Inductive Model. Jenis penelitian yang digunakan ialah Penelitian Tindakan Kelas (PTK), sedangkan subyek penelitian adalah 31 siswa kelas VII-1 SMP Negeri 1 Brang Rea semester genap tahun ajaran 2018/2019. Pengumpulan data dilaksanakan bersamaan dengan pengamatan selama tindakan, sementara analisis data dilaksanakan bersamaan pada saat refleksi
\end{abstract}


tindakan. Dari hasil penelitian diperoleh bahwa PWIM signifikan guna meningkatkan hasil belajar siswa dalam pembelajaran menulis berbahasa Inggris terutama dalam mendiskripsikan benda/orang/tempat tertentu bagi kelas VII-1 semester genap tahun ajaran 2018/2019. Implikasi pedagogis dari penelitian ini adalah, penggunaan strategi PWIM bisa membantu siswa dalam menggali banyak kosa kata untuk kemudian disusun menjadi sebuah paragrap dan teks deskriptif berbahasa Inggris. Dengan melihat gambar benda/orang/tempat tertentu, siswa mendapatkan inspirasi kata apa saja yang akan mereka tulis untuk menyusun sebuah teks deskriptif.

Kata kunci: Picture word inductive model, Teks deskriptif, Prestasi

\section{A. PENDAHULUAN}

Menulis merupakan salah satu keterampilan bahasa yang mesti dipelajari oleh siswa. Denganketerampilan menulis, seseorang dapat mempublikasikan gagasan, pikiran dan perasaannya kepada orang lain (Ela Nurmala, 2018). diantara kelebihan kemampuan menulis dibandingkan dengan kemampuan berbicara ialah seseorang dapat memiliki kesempatan yang lebih banyak dalam merangkai kata-kata perihal menyampaikan gagasan, pikiran dan perasaannya tersebut. Selain hal tersebut, kesalahan seseorang tidak dapat diketahui secara langsung oleh orang lain, sehingga seseorang tidak perlu merasa khawatir dan takut. Namun demikian, ela Nurmala (2018) bahwa dalam menulis tidak hanya sekedar menyusun/ merangkai kata-kata, frasa, atau kalimat. Siswa perlu mengikuti aturan bahasa tertentu untuk bisa memproduksi tulisan yang bisa dipahami dan diterima oleh pembaca. Menurut rangkaian kelangsungan belajar bahasa yang diusulkan oleh Hammond, dan kawan-kawan (2003), menulis lebih baik diberikan kepada siswa SMA pada tingkat akhir. Namun keterampilan menulis secara sederhana bisa diberikan kepada siswa sejak kelas VII.

Tingkat literasi berbahasa Inggris ditingkat siswa SMP adalah tingkat fungsional. Siswa diharapkan memiliki tingkat kemampuan berkomunikasi secara lisan dan tulis dalam menyelesaikan masalah serta dalam memenuhi kebutuhan sehari-hari, misalnya menulis pesan singkat, kartu ucapan atau undangan, pengumuman, dan lain-lain (Juniladri, 2018). Namun demikian, Meskipun tingkat kemampuan literasi yang diharapkan dapat dikuasai siswa hanyalah tingkat yang sangat sederhana, namun tidak mudah juga bagi siswa kelas VIII-1 SMP Negeri 1 Brang Rea untuk dapat langsung mempraktekkannya dengan baik. Banyak belum memiliki kemampuan dalam mengungkapkan makna yang tertuang dalam teks tulis fungsional dan essei pendek sangat sederhana berbentuk deskriptif dan prosedur untuk dapat berinteraksi dengan lingkungan terdekat dengan baik. Untuk mengatasi permasalahan-permasalahan tersebut, peneliti mencoba untuk menerapkan strategi Power Word Inductive Mode/ dalam membantu siswa untuk dapat menemukan sebanyak mungkin kosa kata yang kemudian disusun menjadi frase, kalimat, paragraf dan teks pendek sangat sederhana yang berbentuk dekriptif untuk dapat berinteraksi dengan lingkungan sekitar. Penelitian ini cukup menarik dilakukan dan peneliti memiliki asumsi jika siswa akan dapat menulis 
banyak kosa kata secara bersama-sama dengan menggunakan strategi tersebut.

\section{B. METODE PENELITIAN}

Penelitian ini merupakan penelitian tindakan kelas atau lebih sering dikenal dengan classroom action research untuk meningkatkan hasil belajar siswa kelas VII-1 SMP Negeri 1 Brang Rea semester dua tahun ajaran 2018/2019 dalam pembelajaran menulis berbahasa Inggris guna mengungkapkan berbagai hal yang berhubungan dengan lingkungan terdekat mereka, lebih khususnya adalah mendeskripsikan benda/orang/tempat tertentu. Penelitian ini dilaksanakan dalam tiga (3) siklus dengan metode yang berbeda seperti yang telah diuraikan sebelumnya. Setiap siklus ditempuh dengan empat langkah atau tahap yaitu perencanaan (planning), penerapan tindakan (acting), pengamatan (observing), dan refleksi (reflecting). Setiap penerapan tindakan dilakukan pembelajaran dengan empat (4) tahap, yaitu BKoF, MoT, JCoT, dan ICoT, seperti yang telah diuraikan.

\section{HASIL DAN PEMBAHASAN}

Sebelum diadakan tindakan, tidak banyak siswa kelas VII-1 SMP Negeri 1 Brang Rea semester genap tahun ajaran 2018/2019 bisa mendeskripsikan benda/ orang/tempat tertentu dan itu hanya berupa frase. Meskipun demikian ini merupkan awal yang baik apabila siswa sudah bisa menyusun frase benda dengan benar. Ketika siswa siswa bisa memberikan respon terhadap pertanyaan guru namun hanya berupa sebuah kata. Ketika guru meminta untuk membuat frase, hanya 10 siswa yang meresponnya. Untuk itu perlu diadakan penelitian guna memecahkan permasalahan yang dihadapi para siswa kelas VII-1 SMP Negeri 1 Brang Rea semester dua tahun ajaran 2018/2019. Berbagai faktor mempengaruhi mengapa hal ini bisa terjadi. Namun faktor terpenting adalah kurangnya kosa kata yang mereka miliki. Meskipun kesalahan bahasa tulis tidak langsung diketahui oleh orang lain, namun bahasa tulis lebih kompleks, lengkap dan formal.

Tindakan dalam penelitian ini dilaksanakan sebanyak 3 siklus, dan masingmasing siklus terdiri dari 4 tahap. Tindakan dilakukan dengan metode yang berbeda. Hal ini dimaksudkan untuk mengetahui sejauh mana penggunaan strategi Picture Word Inductive Mode/ bisa meningkatkan hasil belajar siswa kelas VII-1 SMP Negeri 1 Brang Rea semester genap tahun ajaran 2018/2019 dalam pembelajaran menulis berbahasa Inggris. Seperti telah disampaikan sebelumnya, tindakan siklus pertama, siswa mendiskripsikan benda tertentu berkelompok 4 kemudian individu dengan menggunakan strategi PWIM. Tindakan ke dua sama seperti sebelumnya, hanya objek yang dideskripsikan adalah orang tertentu. Sementara pada tindakan ke tiga, siswa mendeskripsikan gambar tempat tertentu berkelompok 4 tanpa prosedur seperti dalam strategi PWIM.

Pada bagian ini tidak lagi dibahas mengenai perencanaan tindakan, namun hanya dibahas hasil pelaksanaan, pengamatan dan refleksi dari masing-masing siklus. Berikut penjelasannya.

\section{Siklus I}

\section{a. Pelaksanaan Tindakan (Acting)}

Tindakan dilaksanakan dalam 4 tahap, seperti pada pembelajaran sehari- 
hari, yaitu Building Knowledge of the Text (BkoF), Modeling of the Text (MoT), Joint Construction of the Text (JCOT), dan Independent Consituction of the Text (ICOT). Namun pengamatan hanya difokuskan pada saat siswa mengikuti tahap Joint Construction of the Text (JCoT), dan Independent Consrtuction of the Text (ICOT). Pada tahap JcoT, siswa bekerja sama untuk menyusun sebuah teks deskriptif tentang benda tertentu dengan tahapan seperti di dalam model.

b. Pengamatan (Observing)

Dari hasil pengamatan tindakan pada siklus I, didapatkan data bahwa belum banyak siswa yang bisa mendiskripsikan benda tertentu dengan benar. Masih banyak siswa yang melakukan kegiatan-kegiatan yang tidak dikehendaki selama pembelajaran seperti mengobrol, saling melihat gambar, menulis dalam bahasa Indonesia, dan bahkan tertawa lebar setelah melihat gambar. Meskipun demikian, pada siklus ini telah terjadi peningkatan hasil belajar siswa dalam pembelajaran menulis berbahasa Inggris, namun belum memenuhi kriteria keberhasilan yang telah ditetapkan, yaitu $75 \%$ dari seluruh siswa mencapai KKM 72. Hanya 20 siswa (64.51\%) berhasil mencapai KKM.

c. Refleksi (Reflexion)

Pada saat dilaksanakan refleksi, siswa menyampaikan bahwa siswa masih menemui kesulitan untuk menuliskan kata-kata yang mendeskripsikan benda tertentu. Guru menyampaikan kembali bahwa yang harus dilakukan siswa pertama kali adalah menyebutkan semua benda yang terlihat di dalam gambar. Siswa tidak perlu terpaku harus menuliskan banyak benda apabila yang ada di dalam gambar memang tidak terdapat banyak benda. Kemudian baru menyebutkan kata yang menerangkan benda tersebut (kata sifat), dan seterusnya. Guru masih belum banyak memberikan bantuan kepada siswa pada siklus ini. Guru masih sibuk mengamati siswa. Dari hasil tersebut, direncanakan dalam tindakan pada siklus ke dua.

\section{Siklus II}

a. Pelaksanaan Tindakan (Acting)

Seperti pada tindakan siklus satu, tindakan pada siklus ini juga dilaksanakan dalam 4 tahap, seperti pada pembelajaran sehari-hari, yaitu Building Knowledge of the Text (BkoF), Modeling of the Text (MoT), Joint Construction of the Text (JCOT), dan Independent Consituction of the Text (ICoT). Berikut penjelasannya.

Pada tindakan siklus ke dua, siswa masih bekerja berkelompok empat kemudian mandiri untuk mendeskripsikan orang tertentu. Pelajaran dimulai dengan mereview cara mendeskripsikan gambar benda tertentu menggunakan prosedur seperti dalam strategi PWIM. Kemudian siswa diminta berlatih melakukannya di depan kelas. Pada kegiatan ini guru mengoreksi siswa apabila terjadi kesalahan dalam mendeskripsikan gambar benda tertentu. Siswa bekerja berkelompok 4 pada tahap JCoT. Pada tahap ini siswa bersama-sama menuliskan beberapa kata benda yang ada di dalam gambar maupun yang berhubungan dengan gambar tapi tidak ada di dalam 
gambar. Kemudian mereka mencoba menuliskan kata sifat apa saja yang bisa menerangkan kata benda tersebut, untuk kemudian disusun menjadi frase kata benda, kalimat, paragraf dan dilanjutkan dengan membuat teks diskriptif.

b. Observasi (Observing)

Pada siklus ini, strategi menulis tidak diubah. Siswa tetap bekerja kelompok berempat dan mendapatkan gambar orang tertentu untuk dideskripsikan dengan strategi $P W I M$. Selama pembelajaran, hampir lebih dari $50 \%$ siswa berhasil belajar. Tidak banyak siswa yang melakukan hal-hal yang tidak diinginkan. Ada 22 siswa (70.96\%) berhasil belajar aktif. Masih ada siswa yang kurang berhasil belajar. Siswa saling memberikan kontribusi tentang kata-kata yang bisa digunakan untuk mendeskripsikan orang tertentu. Guru lebih banyak memberikan umpan balik kepada siswa agar bisa memunculkan kosa kata sebanyak mungkin berdasarkan gambar. Siswa dipersilakan langsung menuliskan kata kata berdasarkan gambar atau mendiskusikannya terlebih dahulu dengan teman dalam kelompokknya.

c. Refleksi (Reflexion)

Berdasarkan refleksi pembelajaran yang dilakukan sesuai kegiatan, didapat keterangan bahwa siswa lebih menikmati kegiatan dengan berbagi kosa kata yang mereka munculkan untuk mendeskripsikan orang tertentu. Untuk membantu memunculkan kosa kata baru dari siswa guru memberikan umpan balik elisitasi. Untuk memastikan apakah peningkatan hasil belajar siswa dalam pembelajaran menulis berbahasa Inggris disebabkan adanya penggunaan Picture Word Inductive Model maka dilakukan tindakan pada siklus ke tiga.

\section{Siklus III}

a. Pelaksanaan Tindakan (Acting)

Seperti pada tindakan kedua siklus sebelumnya, tindakan pada siklus ini juga dilaksanakan dalam empat tahap, yaitu Building Knowledge of the Text (BkoF), Modeling of the Text (MoT), Joint Construction of the Text (JCoT), dan Independent Consrtuction of the Text (ICOT). Berikut penjelasannya. Building Knowledge of the Field (BkoF)

1) Guru mereview cara mendeskripsikan benda dan orang tertentu seperti pada pertemuan sebelumnya.

2) Guru menunjukkan gambar tempat tertentu.

3) Guru mengajukan beberapa pertanyaan yang bisa memancing siswa untuk menyebutkan beberapa kata (kata benda/sifat) tentang gambar tersebut. Contoh:

What picture is it? What can you see in it? Mentionit.

How is it?, dst.

\section{Modeling of the Text (MoT)}

Dengan pengetahuan cara mendeskripsikan benda/orang tertentu pada pertemuan sebelumnya, siswa diajak untuk mendeskripsikan gambar tempat tertentu tanpa melalui prosedur seperti dalam PWIM. 
Joint Construction of the Text (JcoT)

1) Siswa dibagi berkelompok empat.

2) Masing-masing kelompok diberi gambar tempat tertentu yang berbeda.

3) Siswa diminta mendeskripsikan gambar tersebut secara berkelompok empat dengan cara yang sama seperti di dalam contoh/tahap Modeling of the Text yaitu langsung mendiskripsikan gambar tempat tertentu tanpa melalui prosedur PWIM.

4) Guru mengamati pekerjaan siswa sambil mencatat hal-hal yang penting dan memberikan penjelasan.

Independent Construction of the Text (ICOT)

1) Guru mendisplay gambar tempat tertentu.

2) Siswa diminta mendeskripsikan gambar secara individu.

b. Observasi (Observing)

Berdasarkan pengamatan selama tindakan pada siklus ke tiga, diperoleh data bahwa hasil belajar siswa dalam pembelajaran tersebut menurun. Terdapat 26 siswa $(83.87 \%)$ berhasil mendiskripsikan tempat tertentu dengan benar.

c. Refleksi (Reflexion)

Berdasarkan hasil refleksi, didapatkan data bahwa hasil belajar siswa dalam pembelajaran menulis berbahasa Inggris guna mendeskripsikan tempat tertentu mengalami penurunan karena tidak digunakan strategi Picture Word Inductive Mode/ meskipun siswa masih tetap memiliki gambar. Ini membuktikan bahwa penggunaan Picture Word Inductive Model dalam pembelajaran menulis berbahasa Inggris berhasil meningkatkan hasil belajar siswa kelas VII-1 SMP Negeri 1 Brang Rea dalam mendiskripsikan benda/ orang/tempat tertentu. Picture Word Inductive Model terbukti berhasil membantu siswa kelas VII-1 SMP Negeri 1 Brang Rea pada semester genap tahun ajaran 2018/2019 meningkatkan hasil belajarnya dalam pembelajaran menulis berbahasa Inggris, terutama dalam mendeskripsikan benda, orang atau tempat secara sederhana.

Kondisi awal sebelum diadakan tindakan, hanya 14 siswa (45.16\%) bisa mendiskripsikan benda/orang/tempat tertentu berbahasa Inggris. Setelah diadakan tindakan siklus I, ada peningkatan jumlah siswa yang berhasil belajar. 20 siswa (64.51\%) berhasil belajar dalam kegiatan dimaksud. Pada siklus ke dua, jumlah mengalami peningkatan menjadi 22 siswa (82.60\%), dan pada siklus ke 3 ada 17 siswa (73.91\%) berhasil belajar. Dengan demikian hipotesis terbukti.

\section{KESIMPULAN}

Berdasarkan pengamatan selama tindakan, ada perubahan signifikan hasil belajar siswa kelas VII-1 SMP Negeri 1 Brang Reawang semester genap tahun ajaran 2018/2019 dalam mendeskripsikan benda/orang/tempat tertentu ketika digunakan Picture Word Inductive Model. Sebelum diadakan tindakan, hanya 10 
siswa dapat mendeskripsikan benda/orang/tempat tertentu berbahasa Inggris. Ketika diadakan wawancara, diperoleh jawaban penyebab siswa kurang bisa mengikuti pembelajaran menulis berbahasa Inggris, diantaranya adalah a). siswa tidak memiliki bahan apa yang harus dituliskan, dan b). siswa bosan dengan teknik yang terkesan monoton.

Setelah diadakan tindakan sebanyak 3 siklus, ada peningkatan hasil belajar siswa dalam mendeskripsikan benda/orang/tempat tertentu. Pada siklus pertama, siswa diminta menulis teks deskriptif tentang benda tertentu dalam kelompok berempat menggunakan strategi Picture Word Inductive Model. Hasilnya, hanya 12 siswa $(52.17 \%)$ yang dapat mendeskripsikan benda tertentu dengan benar. Masih banyak siswa yang belum bisa melakukannya dengan benar, dan cenderung melakukan kegiatan yang tidak dikehendaki.

Pada siklus ke dua, siswa diminta menyusun teks deskriptif tentang orang tertentu menggunakan stretegi Picture Word Inductive Model. Ada 19 siswa $(82.60 \%)$ yang berhasil mendeskripsikan orang tertentu dengan benar. Hasil sudah mencapai target yang diharapkan. Namun untuk mengetahui apakah Picture Word Inductive Model membantu peningkatan tersebut, maka tindakan dilanjutkan. Pada siklus ke tiga, siswa diminta menulis teks deskriptif tentang tempat tertentu tanpa menggunakan strategi Picture Word Inductive Model. Siswa langsung diminta mendeskripsikan gambar tempat tertentu. Hasilnya, hanya 17 siswa $(73.91 \%)$ yang berhasil belajar aktif.

Dapat disimpulkan bahwa pembelajaran menulis berbahasa Inggris menggunakan media Picture Word Inductive Model dapat meningkatkan keterampilan siwa kelas VII-1 SMP Negeri 1 Brang Rea pada semester genap tahun ajaran 2018/2019 dalam mendeskripsikan benda/orang/tempat tertentu. Kelebihan dari penggunaan Picture Word Inductive Model adalah siswa menjadi lebih bersemangat dalam mengikuti pembelajaran menulis berbahasa Inggris karena mereka terbantu dalam memunculkan kosa kata yang akan mereka gunakan. Selain itu, kontribusi siswa dalam memunculkan kosa kata membuat siswa semakin tertantang. Sementara kekurangan dari penggunaan Picture Word Inductive Mode/ adalah mungkin metode ini hanya bisa meningkatkan hasil belajar siswa kelas VII-1 SMP Negeri 1 Brang Rea pada semester genap tahun ajaran 2018/2019, karena setiap siswa mengalami masalah yang berbeda dan memiliki cara yang berbeda pula dalam belajar. 


\section{DAFTAR RUJUKAN}

Hammond, J., et. al.. (1992). English for Social Purposes: a Handbook for teachers of Adult Literacy. Sydney: NCELTER.

Juniladri. (2018). Penerapan Pendekatan Strategi Power Word Inductive Model Untuk Meningkatkan Pemahaman Siswa Dalam Pembelajaran Bahasa Ingris. $\quad$ https://juniladri.wordpress.com/2018/03/03/penerapanpendekatan-strategi-power-word-inductive-model-untuk-meningkatkanpemahaman-siswa-dalam-pembelajaran-bahasa-ingris/. Dikutip pada Juli 2018.

Nurmala, E. (2019). PENERAPAN STRATEGI PICTURE WORD INDUCTIVE MODEL GUNA MENINGKATKAN HASIL BELAJAR DALAM MENYUSUN TEKS DESKRIPTIF BERBAHASA INGGRIS SISWA KELAS XI IIK-1 MAN 2 SUMEDANG. JURNAL EDUKASI SEBELAS APRIL, 2(2). 